\title{
The Future of Welfare State within European Union in the Time of Crisis: From Financial Crisis to Brexit
}

\author{
Muhammad Syaroni Rofii \\ \{muhammadsyaroni@ui.ac.id\} \\ School of Strategic and Global Studies, Universitas Indonesia, Jakarta Pusat
}

\begin{abstract}
The concept of Welfare State is the approach chosen by countries to protect their weak citizens. Those who have entered the category of aging, pensioners, unemployed are included in the category of groups that receive protection from the state with a social funding scheme. Some EU countries are defenders of the concept of Welfare State. This can be seen from the amount of social funds taken from their budget. The European Union as a regional organization also recommends its members to protect weak citizens with their social funds. However, lately this concept has faced obstacles ranging from the global economic crisis to the Brexit phenomenon. This article also explains about the difficult situation faced by Spain, Greece, and Portugal which has an impact on all members of the European Union. The situation triggers Welfare state adherents to cut their social funds. This article explains the history of Welfare State in the European Union and is followed by problems faced in the contemporary period.
\end{abstract}

Keywords: Welfare state, European Union, Economic crisis, European Social Fund

\section{Introduction}

Welfare state system is a concept of allocation some financial resources for social policy purposes to help the poor. Through this concept government play key role in protecting and promoting the economic and social well-being of its citizens. It is based on the principles of equality of opportunity, equitable distribution of wealth, and public responsibility for those who lack the minimal provisions for a good life. This term used in many variations of forms related to economic and social organization. But the thing that make welfare state different from another concept is social insurance, intended to provide benefits during periods of greatest need for old age, illness, and unemployment [3]. The welfare state also usually includes public provision of education, health services, and housing. Such provisions are less extensive in the U.S. than in many European countries, where comprehensive health coverage and state-subsidized university-level education have been common. In countries with centrally planned economies, the welfare state also covers employment and administration of consumer prices. Most nations have instituted at least some of the measures associated with the welfare state, such as United States, United Kingdom, Scandinavian countries [4].

This article attempt to discuss widely about welfare state system in the European Union countries and forecasting the future of the concept in the middle of crisis especially the impact 
of global economic crisis in 2008 and disintegration of United Kingdom from the European Union (Brexit). In the first part of the paper introduce the meanings of welfare state concept, then in the second chapter will discuss about history and concept of welfare state in European Union at the same time make comparison between UE concept and another types of welfare state, in third part will explain the prediction and possibilities in the future of welfare state in European Union during and after crisis, while the last part is conclusion.

\section{Welfare State: The Basic Concept and Its Purposes}

According to Briggs Welfare State a concept that emerged since the Second World War to describe the complex of social policies enacted under the Labour government in Britain after 1945 [5]. Since that period this concept became popular around the world refer as an instrument of institutional structure which have concern with social policy. The development of this concept brought to evolution of concept denoted by the expansion of the services provided by the welfare state in the twentieth century to cover a widening range of risks [6]. After the Second World War, Welfare State concept became general phenomenon in the world especially in industrial countries then imply to growth of number and typologies of social services provided by the state was a function of its ability to create procedures for defining social policy, earn the funds (through taxation and contributions from business sectors and rich man) to pay for these policies, identify recipients and distribute benefits and services [7].

Values are also embedded in the definition and provision of social policy, and have led to the development of a variety of regimes for the definition and delivery of social policy. For example, British conceptions of social policy are preoccupied with reconciling universal social rights available to all citizens with market efficiency. While Continental social policies, in contrast, have their own way and they are informed by the concept of solidarity. The main thinkers behind French social policy, namely Emile Durkheim, Léon Bourgeois and Pierre Laroque, emphasized the concept of interdependence (solidarism) that created a system of solidarity out of social pluralism [8]. The dominant value in this system was the protection of European Welfare States the individual from risks associated with work - illness, accidents, unemployment - through occupation-based schemes of social security.

According to Gosta Esping Anderson, a Danish sociologist, made three categories of European States Welfare system including: Nordic model, Continental model, and Anglo Saxon. These types have rooted from character of each countries, where Nordic (social democratic) welfare states are predicated on social investment strategies that promote higher employment and growth, ensuring 'cradle to grave' provision in child care and social care for the elderly. While Continental (conservative) welfare states, maintain contributory social insurance systems that offer high levels of protection to 'insiders', while continuing to regulate employment and the labour market. Then, Anglo-Saxon (liberal) welfare states, have undergone something of a transition, adopting elements of the social investment approach. Nonetheless, welfare benefit levels remain relatively low, there is significant reliance on targeting and means-testing, and a considerable proportion of state services have been privatized [9]. 


\begin{tabular}{|c|c|c|c|}
\hline & Liberal & Conservative & Social-democratic \\
\hline Decommodification & Low & Medium & High \\
\hline Stratification & $\begin{array}{l}\text { Dual: means-tested } \\
\text { programs } \\
\text { promoting market } \\
\text { in social provision }\end{array}$ & $\begin{array}{l}\text { High: insurance- } \\
\text { based schemes to } \\
\text { preserve social } \\
\text { rights according to } \\
\text { status }\end{array}$ & $\begin{array}{l}\text { Low: universal } \\
\text { entitlements } \\
\text { for preserving } \\
\text { equality }\end{array}$ \\
\hline Examples & $\begin{array}{l}\text { United States, UK, } \\
\text { New Zealand, } \\
\text { Ireland }\end{array}$ & $\begin{array}{l}\text { Germany, } \\
\text { Switzerland, } \\
\text { France, Austria }\end{array}$ & $\begin{array}{l}\text { Sweden, Finland, } \\
\text { Norway }\end{array}$ \\
\hline
\end{tabular}

Source: G. Esping Andersen, The Three World of Welfare Capitalims, 1990)

Since Esping Andersen introduce general model of welfare state in the world and he automatically associated as an expert of welfare state system, however we also could not ignore another term which emerge not in Europe but outside Europe. Welfare states do not always institute 'politics against markets', as commonly assumed: social policies can also serve a productive function. Social policy does play a role in shaping economic structures such as financial governance, labour markets, and bargaining practices. Comparing Welfare Capitalism makes a strong case for the idea that particular welfare state regimes and certain political economies reinforce each other through 'institutional complementarities'[10].

\section{Welfare States Practice in European Union}

European Union known as a role model for developing concept of regional organization by adopting common law to all member countries. Through its power the EU can force every member to comply with law regarding social model fund or social policy implementation [11]. Existence of this mechanism allow the EU to protect the poor through strict law, for this reason Alberto Alesina and Edward Glaeser called the EU as a home of social altruism. Based on their study explained that the EU spend more money for social policy than the US done. For this reason, Dominique Moisi from French Institute for International Relations mentioned that the EU, "represents a very important part of the European identity. I would say that it is one of Europe's biggest comparative advantages, not only in the economic sense, but in the social and humane aspect as well." The EU governments redistribute income among their citizens on a much larger scale than does the US government and European social programs are more generous and reach a larger share of citizens (the below table 1 showed that the comparison of expenditure between EU states and United States), while tax systems also more progressive, at the end European regulations designed to protect the poor are more intrusive [12].

Apart from the debate about why social spending of European government larger than the US the answer we can propose that because paradigm of welfare state as a social altruism in Europe more dominant. People of United States do not support the idea of giving money to the poor without work and they perceived that situation of poor people because they are lazy. While in contrast, Europeans people tend to believe that the poor are poor because they have been 
unfortunate [13]. State should take a part to help unfortunate people and social policy is the way to take care of them. European Union also concern with the common values of their region, including: solidarity, social justice, social cohesion, equal access to employment, gender equality, equal access to health and social protection, universal access to education, universal access to health and social services, equal opportunities for everybody in society, in particular the elderly, the young, the disabled, the socially excluded and minority groups, social rights and european citizenship.

Table 1. Composition of General Government Expenditure, 1999

\begin{tabular}{|c|c|c|c|c|c|c|}
\hline \multirow[b]{2}{*}{ Country } & \multirow[b]{2}{*}{ Total } & \multicolumn{2}{|c|}{ Consumption } & \multirow[b]{2}{*}{ Subsidies } & \multirow{2}{*}{$\begin{array}{c}\text { Transfers } \\
\text { and other } \\
\text { social } \\
\text { benefits }^{\mathrm{b}}\end{array}$} & \multirow[b]{2}{*}{$\begin{array}{c}\text { Gross } \\
\text { investment }\end{array}$} \\
\hline & & $\begin{array}{l}\text { Goods } \\
\text { and } \\
\text { services }\end{array}$ & $\begin{array}{c}\text { Wages } \\
\text { and } \\
\text { salaries }\end{array}$ & & & \\
\hline United States $^{c}$ & 35.5 & 5.2 & 9.2 & 0.2 & 11.0 & 3.1 \\
\hline European Union ${ }^{\mathrm{d}}$ & 47.9 & 8.4 & 12.0 & 1.5 & 18.1 & 2.8 \\
\hline France & 51.0 & 10.0 & 13.7 & 1.3 & 20.1 & 3.0 \\
\hline Germany & 47.4 & 10.7 & 8.3 & 1.7 & 20.5 & 1.8 \\
\hline Sweden & 60.2 & 10.3 & 16.7 & 2.0 & 21.1 & 2.5 \\
\hline United Kingdom & 38.3 & 11.0 & 7.4 & 0.6 & 15.7 & 1.0 \\
\hline
\end{tabular}

Source: OECD Economic Outlook, 2000.

If we look back at the history of the European countries, we can concluded that after the Second World War, European leaders concern with development and were seeking a framework and a mechanism that would help prevent future conflicts between states. The development of European Union which started from the original six founding states then expanded become 27 member states unified in decision making and cooperation system. The Treaty Establishing the European Community (TEC) laid down the fundamental social goals that should be fulfilled: a) promotion and strengthening of employment, b) improvement of living and working conditions, c) adequate social protection, d) dialogue between management and employees, e) development of human resources with the goal of maintaining high employment levels and fighting against social exclusion [14].

During the time of the formation of the EU, there were no especially ambitious plans for the development of a common social policy. The original Treaty of Rome did not exclude social issues, but they were not frequently mentioned. More extensive social policies began to be implemented only after the formation of the single market. The European Union received broader authorization in the field of social policy through the passage of the Single European Act and the Maastricht Treaty, which supplemented the Treaty of Rome [15]. The priorities of social policies changed over time, along with the socio-economic and political changes on the international and domestic scenes [16]. During the first years, the basic goals of social policy were: improvement of living and working conditions; ensuring high levels of employment and social protection; gender equality; raising the standards and quality of life; prohibiting 
discrimination on the basis of gender, race, ethnicity, religion, invalidity, age; ensuring the free movement of the labor force between states; free formation of institutions, etc [17].

Policy making process in the social policy field at the regional level in Europe now includes three distinct forms of governance by the European Union: governance by EU law, governance by EU-level bargaining between employers' and workers' associations in the Social Dialogue, and the governance of employment policy in the form of the European Employment Strategy. These diverse and complex modes of regional governance in the social policy field have emerged over a short period of time. While governance by EU law was included in the Treaty of Rome on the basis of unanimity voting in a highly limited number of issue areas, qualified majority voting was not introduced until the Single European Act (1987).

Subsequent Treaty revisions of Maastricht (1993), Amsterdam (1999), and Nice (2002) have each resulted in the expansion of EU competence in the social policy field, and in new forms of governance. Policymaking, while necessarily continuing to involve states, also extends to the global level through the activities of the International Labor Organization (ILO). Supranational governance remains largely limited, however, to a narrow range of social policy best described as 'social regulation' which, while providing basic rules for the operation of the labour market and employment contract, does not involve large fiscal transfers to the individual.

According to the procedure introduced by EU Laws that every country has the obligation and rights to ratify those laws. So, every countries in EU from Nordic to Mediterranean has same umbrella to help their people by social policies (graphic 2 explains about social spending of EU member states which has strong foundation in social policy). Sweden, Norway and other Scandinavian countries helped their poor people, guarantying university budget, guarantying free hospital for every citizen before participating in European Union mechanism. Great Britain as a representative of Anglo Saxon model also did the same but proposes reformation as a way to adjust their economic situations and economic plan by new regime. Germany which identical with Bismarckian introduces another approach to help their people but the spirit is same that to make sure every citizen safe from wave of liberal market and fundamentalist values of capitalism which never let state intervention in any kinds [18].

Even, European Commission did special research to make measurement about the performances of social policies in every EU member states, research organized by European Commission in cooperation with Growth and Sustainability Policies for Europe, they conclude that the purpose of research is to prepare guidelines for measurement of performance of social protection in Europe, the result from that research is at least two things, first after interviewing EU citizens with questionable indicators they can make conclusion about citizens responses to their governmental performances, second point, the European Commission realize that between old member state which has stable foundation of welfare state easier to adopt EU standard and the members if they could not perform as expected then the Commission will give supervision to speed up the process of adjustment [19]. 


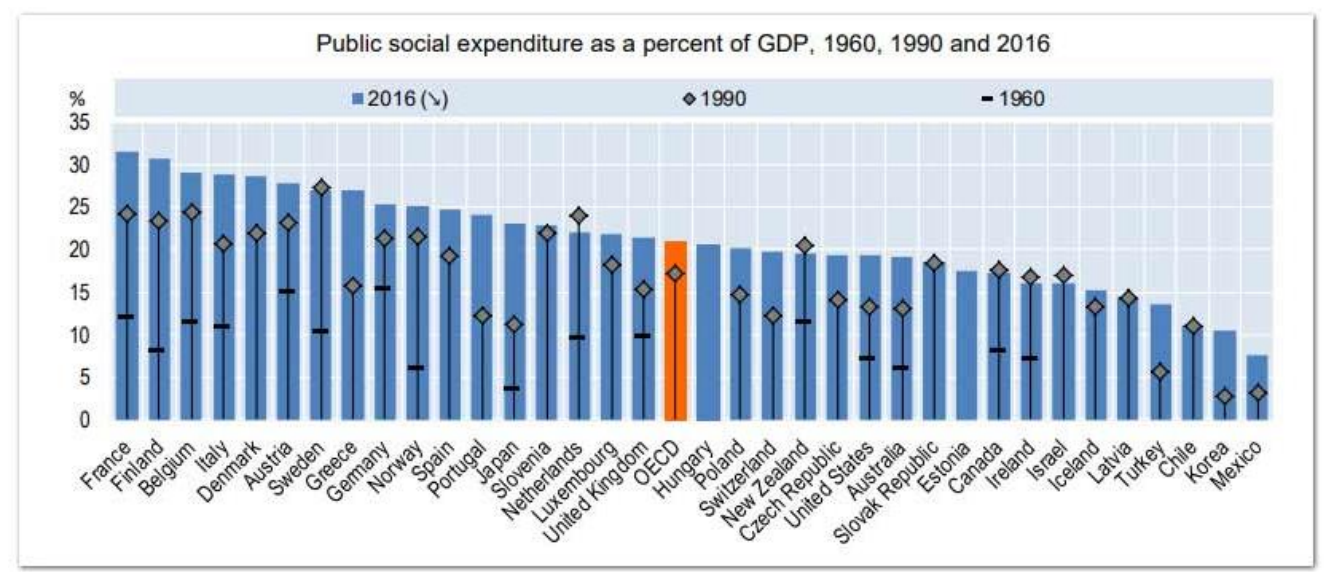

Source: OECD Social Expenditure Update 2016, OECD

\section{Welfare in the Time of Crisis and EU's 2020 initiatives}

With economic crisis still happens, European Union leaders still searching the way to cure illness in heart of their economic problem. During the economic crisis Greece increase the debt and reducing the cost of social protection. Cyprus also did the same to continue growth of economic activity based of advice of Bank Central of Europe, Italia, Portugal, Spain and some European Countries face the same problem of decline in economy. The situation shock the world because of the impact of that global economic crisis in 2008 affecting most of EU countries. During period of crisis industrial production fell drastically. Its marked by world industrial output dropped by $13 \%$ from peak to trough in what was definitely a deep recession, it fell by nearly $40 \%$ in the 1930s. American and European unemployment rates rose to barely more than $10 \%$ in the recent crisis; they are estimated to have topped $25 \%$ in the 1930 s [20].

The global economic crisis directly affects the financing of the social protection system, especially for two reasons: first, with increased unemployment rates, the costs of the funds of social insurance and state expenditures related to social protection will grow; then in the second, their proceeds from taxes and contributions are falling, as a result of lower economic growth and lower wages. Ever since the majority of states have adopted credit-financed aid packages in response to the economic crisis and in order to help the financial sector, cumulatively higher deficits in state and social insurance fund budgets have begun to appear. If the crisis is overcome any time soon and the European economy reclaims its high growth rates, member states' comprehensive indebtedness could be fixed without much difficulty. However, the situation will be different if economic growth in the post-crisis period is lower than before the crisis. If growth rates remain below earlier predicted levels of potential growth and unemployment remains high for a longer period, state budgets will be faced with prolonged and bigger difficulties. Reduced social spending and benefits accompanied by tax and contribution hikes might become the main issue of the day very quickly.

According to the European Commission, unemployment in 2010 rose above $10 \%$, while social expenditures rose from $27.5 \%$ to $30.8 \%$ of GDP between 2007 and 2010. From the beginning of the crisis, the ranks of the unemployed have swelled by five million, while the income of many households fell, thus exposing them to risk of poverty and increased 
indebtedness and, in some cases, even loss of home [21]. So, this crisis could be worse than what was happened during the economic crisis in 1930s when European states faced the collapse of economic foundation and how the people reacted to those conditions, it is not impossible if this situation continues then the same condition like 1930s will resurgent. The UE leaders have no choice except cutting the budget for social policy as seen in Greece at the same time Angela Merkel angry because of Greece choice to cut social budget or former French President Nicolas Sarkozy postponed and enlarge the period of pensions from 60 to 62 in order to maximize the role of workers in office and minimizing expenditure which responded by protest in the street [22].

Ulrich Beck in his interview mention that Germany became the most powerful economic power in the European Union, the lack of British influence in term of release veto become a chance for Germany to be more dominant in the European Union. Fact that the central bank of the European Union located in Germany and strategic economic policy only will allowed if big power give permission. If EU leader could not pass this exam then the mission of harmonization among EU states will failed, because if we look at the history of the formation of the European Union is a history of peace between the neighboring countries in the European Union. United Kingdom after the loss of influence on the world stage, Germany is back as an actor after losing influence in times of war. With the presence of the European Union into a new identity for them to restore the effect on the global level, because by bringing together the power of the European Union changed to represent the identity of the identity of all its members. And, EU has many choices to continue to survive from this economic turbulence and to make sure the people of Europe always become a priority in terms of social policy under welfare state paradigm.

One of the last hopes to protect the welfare of EU people is maximizing European Social Fund in promoting the values of Europe for social policy. Through the mechanism of the European Social Fund which usually has allocated 10 percent of the total EU funds, could give major contribution in the field of assistance to address unemployment, poverty, education, and pensions for all citizens of the European Union. The ESF was part of the original Treaty establishing the European Economic Community in 1957. The aim then was to promote employment and increase opportunities for workers. Fifty years later, employment is still a top priority. European efforts have evolved to confront new challenges and to offer better opportunities to all its people.

Refer to the EU target of 2020 that they wanted to create a network that could secure the future of European youth and the economy as a whole. Expected to achieve the 2020 targets of member countries into the European Union can come back after the economic power in recent years of economic decline. Through the ESF, Europe invests more than 10 billion euro a year in its citizens. European Social Fund (ESF) actually had special job to increasing the performance of new members of European Union which has lack of capacity to adapt social policy by European Union Standard. 10 percent budget for could accessed by whole member, especially new member in case they need that budget under supervision of European Commission. ESF also focus their work to supervise and accompany whole citizen of EU to seek the job by facilitating them with educational skill. But, the situation today unpredictable when ESF founded, therefore this institution must be proactive to help European Union especially to decrease amount of unemployment as a result of economic crisis.

It also must be acknowledged that Britain's exit from the European Union or what is termed Brexit is a complicated situation for EU leaders. Because, besides England came out in a situation that is not right, but also the subsequent impact caused by it. When the UK exited this meant that the European Union and the United Kingdom had to renegotiate about specific parts related to trade tariffs. The exit of Britain also changed the composition of policy makers, 
because so far Britain along with Germany and France were countries that were highly respected by all members. World respect for the European Union cannot be separated from the existence of Britain in the organization of the European Union region. Therefore, when the British left it was a great loss for regional organizations.

Another phenomenon that can be seen related to the exit of Britain from the European Union is the emergence of new political movements that promote narrow nationalism. Nationalism based on the national interests voiced by ultranationalist ideologists from the right wing. In the case of Britain, Brexit is an initiative of the right wing groups initiated by Nial Farrage and Boris Jhonson, both of whom present the argument that a country will return to its former glory when the presence of foreigners or migrants must be minimized or eliminated. When this movement was successful, a similar movement began to emerge in France through the figure of Marie Le Pen, who tried to use a similar approach to win electoral contestation. A scene that contrasts with the face of the European Union which has been supporting the ideas of universalism.

\section{Conclusion}

Since the 2008 global economic crisis, the European Union has been trying to find a balance because since that event the European Union has not been able to return to the level where it should be. The European Union hasn't reached its best level since it was first established. Included in efforts to ensure those who are included in social security get protection. This is caused by a very large budget relocation to deal with the crisis that hit countries like Greece, Portugal and Spain.

The crisis that struck Greece, Portugal and Spain had a significant impact on member countries, because the crisis in the south would have an impact on those in the north, in a simpler explanation that those who lost their jobs in the south would try to migrate north in search of decent work that can keep them alive. At the same time trying to get social security guarantees.

Again, the problems faced by the European Union lead to the weak economic resilience of their members because they do not have a comparative advantage. They must compete with fellow member countries who have the same ability in the same sector.

Furthermore, a factor which also cannot be negated as a factor that drives the slow recovery of the European Union is internal conflict. It must be admitted that the locomotives which determine the direction of the European Union are currently in the hands of Germany, France and the United Kingdom. These three countries play an important role in the European Union. Especially for Britain, this country even openly tried to withdraw from the European Union amid the economic crisis that has not yet been completed.

The exit of the UK from the European Union or the so-called Brexit is of course a burden for EU leaders. Because they have to rebuild the same perception among fellow members so that no new currents want to follow England. Because if there are one or two countries that want to leave, then the burden of the European Union will certainly be heavier. For the time being, it can be seen that the long negotiations between the leaders of the European Union and the United Kingdom show that there is an integral attachment when they are united and it is difficult to separate because of the rules that have been binding on them.

Based on the above analysis, it can be concluded that the future of the Welfare State system is in jeopardy, because EU member states must recalculate how much social funds are needed amid the economic recovery needs of the crisis, as well as changes in the composition of citizens 
who have changed due to migration to other consideration factors. Furthermore, the future of the Welfare State system in the European Union will also depend on the ruling regime that leads, because the attachment between the ideology of the leader and the policies taken are closely related to one another. So, for now it can be said that the concept of Welfare State is undergoing an examination, is undergoing a reduction in the amount of budget allocation, to the point that it leads to the removal of the social funding scheme.

\section{References}

[1] Karl Polanyi in Stephan Haggard and Robert Kaufman, Development, Democracy and Welfare State, Latin America, East Asia, and Eastern Europe, (Princeton : Princeton University Press, 2008), page $\mathrm{xv}$.

[2] "Welfare State," in http://global.britannica.com/EBchecked/topic/639266/welfare-state, accessed 20 March 2013;

[3] Ailish Johnson, European Welfare State and Supranational Governance (New York: Palgrave Macmillan, 2005), page 5.

[4] Bruno Palier, A Long Goodbye to Bismarck, The Politics of Welfare Reform in Continental Europe (Amsterdam: Amsterdam University Press, 2010), page 13.

[5] Gosta Esping-Andersen, The Three Worlds of Welfare Capitalism, (Oxford: Polity Press, 1990), page 26.

[6] I. Raluca, Types of Welfare States in the European Union, in http://www.suite101.com/content/types-of-welfare-states-in-the-european-union-a11225424, April 2009.

[7] Bernhard Ebbinghaus and Philip Manow, Comparing Welfare Capitalism: Social Policy and Political Economy in Europe, Japan and the USA, (New York and London: Routledge, 2001).

[8] Stephan Haggard and Robert Kaufman, Development, Democracy and Welfare State, Latin America, East Asia, and Eastern Europe, (Princeton: Princeton University Press, 2008).

[9] Alberto Alesina, Erdward Glaeser and Bruce Sacerdote, "Why Doesn't the United States Have a European-Style Welfare State?", Brookings Papers on Economic Activity, 2001. Page 1-3.

[10] Rafael Muñoz de Bustillo Llorente, Key challenges for the European Welfare States, JRC Working Papers Series on Labour, Education and Technology 2019/04, https://ec.europa.eu/jrc/sites/jrcsh/files/jrc117351.pdf.

[11] OECD Social Expenditure Update 2016, http://www.oecd.org/els/soc/OECD2016-SocialExpenditure-Update.pdf.

[12] Adema, W., P. Fron and M. Ladaique (2011), "Is the European Welfare State Really More Expensive?: Indicators on Social Spending, 1980- 2012 and a Manual to the OECD Social Expenditure Database (SOCX)", OECD Social, Employment and Migration Working Papers, No. 124, OECD Publishing. http://dx.doi.org/10.1787/5kg2d2d4pbf0-en.

[13] Guardian, "Would we have had social enterprise without Margaret Thatcher?", in http://socialenterprise.guardian.co.uk/social-enterprise-network/2013/apr/17/social-enterprisemargaret-thatcher, accessed 27 May 2013.

[14] Alberto Alesina, Erdward Glaeser and Bruce Sacerdote, "Why Doesn't the United States Have a European-Style Welfare State?", Brookings Papers on Economic Activity, 2001. Page 2.

[15] Jelena Batic, "Crisis of the Welfare State in the European Union, the Impact of the World Financial Crisis on the Welfare State," Megatrend Review, Vol 8 (2) 2011: pp. 141-168.

[16] Economist "Lessons of the 1930s, There could be trouble ahead,", http://www.economist.com/node/21541388, accessed 27 May 2013.

[17] See Council of The European Union: Social Protection Committee Contribution, Europe 2020 Strategy (EPSCO).

[18] Patrick Diamond and Guy Lodge, "European Welfare States after the crisis", Policy Network 
Paper, IPPR, January 2013.

[19] Dominique Moisi, "France: A Welfare State Living Beyond Its Means", http://www.digitalnpq.org/archive/1996_spring/france.html, accessed 25 May 2013.

[20] Kersbergen, K., Vis, B. and Hemerijck, A. (2014): "The Great Recession and Welfare State Reform: Is Retrenchment Really the Only Game Left in Town?”, Social Policy \& Administration, vol. 48, pp. 883- 904.

[21] Huber, P., and Oberdabernig, D. A. (2016): "Decomposing Welfare Wedges: An Analysis of Welfare Dependence of Immigrants and Natives in Europe", Kyklos, vol. 69(1), pp. 82-107. 